\title{
RESEARCH
}

Open Access

\section{Basic fibroblast growth factor regulates phosphate/pyrophosphate regulatory genes in stem cells isolated from human exfoliated deciduous teeth}

Nunthawan Nowwarote ${ }^{1}$, Waleerat Sukarawan ${ }^{1,2}$, Prasit Pavasant ${ }^{1,3}$, Brian L. Foster $^{4}$ and Thanaphum Osathanon ${ }^{1,3,5^{*}}$ (i)

\begin{abstract}
Background: Basic fibroblast growth factor (bFGF) regulates maintenance of stemness and modulation of osteo/ odontogenic differentiation and mineralization in stem cells from human exfoliated deciduous teeth (SHEDs). Mineralization in the bones and teeth is in part controlled by pericellular levels of inorganic phosphate $\left(\mathrm{P}_{\mathrm{i}}\right)$, a component of hydroxyapatite, and inorganic pyrophosphate $\left(\mathrm{PP}_{\mathrm{i}}\right)$, an inhibitor of mineralization. The progressive ankylosis protein (gene ANKH; protein ANKH) and ectonucleotide pyrophosphatase phosphodiesterase 1 (ENPP1/ ENPP1) increase $P P_{i}$ and inhibit mineralization, while tissue-nonspecific alkaline phosphatase (ALPL; TNAP) is a critical pro-mineralization enzyme that hydrolyzes $\mathrm{PP}_{\mathrm{i}}$. We hypothesized that regulation by bFGF of mineralization in SHEDs occurs by modulation of $\mathrm{P}_{\mathrm{i}} / \mathrm{PP}_{\mathrm{i}}$-associated genes.

Methods: Cells were isolated from human exfoliated deciduous teeth and characterized for mesenchymal stem cell characteristics. Cells were treated with bFGF, and the osteogenic differentiation ability was determined. The mRNA expression was evaluated using real-time polymerase chain reaction. The mineralization was examined using alizarin red $\mathrm{S}$ staining.

Results: Cells isolated from primary teeth expressed mesenchymal stem cell markers, CD44, CD90, and CD105, and were able to differentiate into osteo/odontogenic and adipogenic lineages. Addition of $10 \mathrm{ng} / \mathrm{ml} \mathrm{bFGF}$ to SHEDs during in vitro osteo/odontogenic differentiation decreased ALPL mRNA expression and ALP enzyme activity, increased ANKH mRNA, and decreased both $\mathrm{P}_{\mathrm{i}} / \mathrm{PP}$ r ratio and mineral deposition. Effects of bFGF on ALPL and ANKH expression were detected within $24 \mathrm{~h}$. Addition of $20 \mathrm{mM}$ fibroblast growth factor receptor (FGFR) inhibitor SU5402 revealed the necessity of FGFRmediated signaling, and inclusion of $1 \mathrm{\mu g} / \mathrm{ml}$ cyclohexamide (CHX) implicated the necessity of protein synthesis for effects on ALPL and ANKH. Addition of exogenous $10 \mu \mathrm{m}$ PP, inhibited mineralization and increased ANKH, collagen type 1a1 (COL 1A1), and osteopontin (SPP1) mRNA, while addition of exogenous $\mathrm{P}_{\mathrm{i}}$ increased mineralization and osterix (OSX), $A N K H$, SPP1, and dentin matrix protein 1 (DMP1) mRNA. The effects of $\mathrm{PP}_{\mathrm{i}}$ and $\mathrm{P}_{\mathrm{i}}$ on mineralization could be replicated by short-term 3- and 7-day treatments, suggesting signaling effects in addition to physicochemical regulation of mineral deposition.

(Continued on next page)
\end{abstract}

\footnotetext{
* Correspondence: thanaphum.o@chula.ac.th

${ }^{1}$ Center of Excellence for Regenerative Dentistry, Chulalongkorn University, Bangkok 10330, Thailand

${ }^{3}$ Department of Anatomy, Faculty of Dentistry, Chulalongkorn University, 34 Henri-Dunant Road, Bangkok 10330, Thailand

Full list of author information is available at the end of the article
}

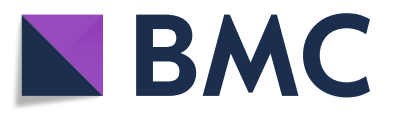

C The Author(s). 2018 Open Access This article is distributed under the terms of the Creative Commons Attribution 4.0 International License (http://creativecommons.org/licenses/by/4.0/), which permits unrestricted use, distribution, and reproduction in any medium, provided you give appropriate credit to the original author(s) and the source, provide a link to the Creative Commons license, and indicate if changes were made. The Creative Commons Public Domain Dedication waiver (http://creativecommons.org/publicdomain/zero/1.0/) applies to the data made available in this article, unless otherwise stated. 
(Continued from previous page)

Conclusion: This study reveals for the first time the effects of bFGF on $\mathrm{P}_{\mathrm{i}} / \mathrm{PP}$ i regulators in SHEDs and implicates these factors in how bFGF directs osteo/odontogenic differentiation and mineralization by these cells.

Keywords: Basic fibroblast growth factor, Stem cells isolated from human exfoliated deciduous teeth, Phosphate, Pyrophosphate

\section{Background}

Basic fibroblast growth factor (bFGF; also known as FGF2) is a member of the fibroblast growth factor family of related signaling molecules crucial for development, maintenance, and repair of tissues. While it regulates various cell processes including proliferation, migration, and differentiation, bFGF also controls maintenance of stemness in human stem cells $[1,2]$. In this regard, bFGF preserves the undifferentiated state of human pluripotent stem cells [3]. Downregulation of OCT3/4 is observed in human embryonic stem cells treated with fibroblast growth factor receptor (FGFR) inhibitor, suggesting a role for bFGF in regulation of genes governing pluripotency [4]. Hence, bFGF is employed as one of the key components in growth medium for human embryonic stem cells and human induced pluripotent stem cells.

Stem cells isolated from human exfoliated deciduous teeth (SHEDs) were reported in 2003 [5]. The appeal of these postnatal mesenchymal stem cells (MSCs) is that they can be obtained non-invasively (isolated after natural exfoliation of primary teeth) and show the multipotent ability to differentiate into osteogenic, adipogenic, and neurogenic lineages [6]. Although they are considered to be MSCs based on known developmental processes, SHEDs exhibit novel characteristics compared with bone marrow-derived MSCs, possibly due in part to their origin from cranial neural crest-derived ectomesenchyme and/or different patterns of signaling that occur in the craniofacial-dental region compared to the postcranial skeleton [5].

Functions of bFGF have been established in regulating some aspects of SHED biology. As it does for embryonic stem cells, addition of bFGF to culture medium maintains stemness in SHEDs in long-term culture [7]. In this context, bFGF enhances colony-forming unit (CFU) ability and the expression of pluripotent markers (e.g., OCT4, REX1, and NANOG) [7], but does not influence cell proliferation $[7,8]$. bFGF plays a potent role in regulating the differentiation of SHEDs into an odontoblast-like phenotype. Previous reports demonstrate that bFGF attenuates tissuenonspecific alkaline phosphatase (gene: ALPL; protein: TNAP) expression and mineral deposition by SHEDs and dental pulp stem cells (DPSCs), in vitro $[1,9]$. bFGF inhibits RUNX2 and BGLAP mRNA expression as well as mineral deposition by SHEDs in vitro via the regulation of ERK and Wnt signaling [8]. In addition, bFGF treatment of SHEDs leads to the reduction of ectopic bone formation in vivo [8].
Further, inhibition of endogeneous bFGF function using a chemical inhibitor of fibroblast growth factor receptor (FGFR) leads to increased mineralization upon osteogenic induction [6]. Correspondingly, SHEDs transfected with shRNA against bFGF exhibit higher mineral deposition than controls [6]. All of this accumulated evidence strongly supports a negative influence of bFGF on differentiation of SHEDs into mature, mineralizing odontoblast-like cells.

Inorganic phosphate $\left(\mathrm{P}_{\mathrm{i}}\right)$ and pyrophosphate $\left(\mathrm{PP}_{\mathrm{i}}\right)$ play crucial roles in physiological and pathological extracellular matrix (ECM) mineralization. $\mathrm{P}_{\mathrm{i}}$ is a primary component of hydroxyapatite crystals that are deposited in the biomineralization of the bone and teeth, while $\mathrm{PP}_{\mathrm{i}}$ is a potent inhibitor of crystal precipitation and growth [10]. In addition to their physicochemical roles in mineralization, both $\mathrm{P}_{\mathrm{i}}$ and $\mathrm{PP}_{\mathrm{i}}$ have been reported to have signaling effects on cells, though mechanisms remain incompletely understood. The addition of $\mathrm{P}_{\mathrm{i}}$ promoted mineralization in rat osteoblasts [11]. Conversely, $\mathrm{PP}_{\mathrm{i}}$ supplementation resulted in reduction of mineral deposition in vitro with reduced cell proliferation and collagen synthesis in murine cementoblasts [12]. Local pericellular $\mathrm{P}_{\mathrm{i}}$ and $\mathrm{PP}_{\mathrm{i}}$ concentrations are regulated by TNAP, ectonucleotide pyrophosphatase/phosphodiesterase-1 (ENPP1;ENPP1), and the progressive ankylosis protein ( $A N K H ; \mathrm{ANKH}$ in humans and $A n k / \mathrm{ANK}$ in mice) [10]. TNAP cleaves extracellular $\mathrm{PP}_{\mathrm{i}}$ into $\mathrm{P}_{\mathrm{i}}$, facilitating ECM mineralization. ENPP1 increases extracellular $\mathrm{PP}_{\mathrm{i}}$ by cleaving nucleotide triphosphates, while $\mathrm{ANKH}$ regulates transport of intracellular $\mathrm{PP}_{\mathrm{i}}$ to the extracellular space. Functions of ANKH and ENPP1 result in increased extracellular $\mathrm{PP}_{\mathrm{i}}$ and subsequently inhibit mineralization. Studies on human loss-of-function mutations and genetically engineered mouse models have demonstrated that TNAP, ENPP1, and ANKH/ANK have profound effects on skeletal and dental mineralization [12-18].

To date, little is known about how bFGF affects expression of $\mathrm{P}_{\mathrm{i}} / \mathrm{PP}_{\mathrm{i}}$ regulators. Studies using MC3T3.E1 murine pre-osteoblasts showed that bFGF upregulates Enpp1 and Ank mRNA expression, while Alpl mRNA levels are downregulated [19]. Another report demonstrated that bFGF inhibits ALPL expression in SHEDs [9]. However, an influence of bFGF on the other key $\mathrm{P}_{\mathrm{i}} / \mathrm{PP}_{\mathrm{i}}$ regulatory genes in SHEDs has not yet been investigated, making it unclear how these genes contribute to bFGF regulation of osteo/odontoblast differentiation and mineralization. In the present study, we aimed to investigate in SHEDs the 
effect of bFGF on $\mathrm{P}_{\mathrm{i}}$ and $\mathrm{PP}_{\mathrm{i}}$ regulatory genes and roles of $\mathrm{P}_{\mathrm{i}}$ and $\mathrm{PP}_{\mathrm{i}}$ on mineralization of SHEDs.

\section{Methods \\ Cell isolation and culture}

The study was approved by Human Research Ethics Committee, Faculty of Dentistry, Chulalongkorn University (Approval number 2015-007). The procedure was performed according to the Declaration of Helsinki. Informed consent was obtained from parents. Primary teeth with no pathological lesions scheduled for extraction according to the clinical treatment plan were collected and stored in culture medium. Dental pulp tissues were obtained, and an explantation protocol was applied for cell isolation, using $35-\mathrm{mm}$ tissue culture plate $[2,6]$. The migrated cells were subcultured when cell confluence was achieved. Cells were cultured in Dulbecco's modified Eagle medium (DMEM, Gibco, USA) supplemented with $10 \%$ fetal bovine serum (Gibco, USA), 2 mM L-glutamine (Gibco, USA), $100 \mathrm{U} / \mathrm{mL}$ penicillin (Gibco, USA), $100 \mu \mathrm{g} / \mathrm{mL}$ streptomycin (Gibco, USA), and $5 \mu \mathrm{g} / \mathrm{mL}$ amphotericin B (Gibco, USA). Cells were maintained in $100 \%$ humidity at $37^{\circ} \mathrm{C}$ and $5 \%$ carbon dioxide.

In experiments described below, cells were treated with the following reagents: $10 \mathrm{ng} / \mathrm{ml}$ recombinant human bFGF (Invitrogen, USA), $20 \mathrm{mM}$ FGFR inhibitor (SU5402; Calbiochem, USA), $5 \mathrm{mM}$ sodium phosphate $\left(\mathrm{Na}_{2} \mathrm{HPO}_{4}\right.$; Sigma-Aldrich, USA), $10 \mathrm{uM}$ sodium pyrophosphate tetrabasic $\left(\mathrm{Na}_{4} \mathrm{O}_{7} \mathrm{P}_{2}\right.$; Sigma-Aldrich, USA), and $1 \mu \mathrm{g} / \mathrm{ml}$ cyclohexamide (CHX; Sigma-Aldrich, USA). ALP was generously provided by Assistant Professor Jeerus Sucharitakul (Faculty of Dentistry, Chulalongkorn University, Thailand).

\section{Flow cytometry}

Single cell suspensions were obtained by detaching cells with trypsin/EDTA solution. Cells were centrifuged, and the supernatant culture medium was discarded. Cells were rinsed with 1\% FBS in PBS and further immunostained with primary antibodies conjugated to fluorescent dye, including anti-human CD44 (BD Bioscience Pharmingen, USA), PerCP-CyTM5.5-conjugated antihuman CD90 (BD Bioscience Pharmingen, USA), PE-conjugated anti-human CD105 (BD Bioscience Pharmingen, USA), and PerCP-conjugated anti-CD45 (BD Bioscience Pharmingen, USA). Cells were analyzed using a FACSCalibur flow cytometer using CellQuest software for operation and gating (BD Bioscience, USA).

\section{Osteo/odontogenic induction}

Cells were seeded in 24-well plates at a density of 50,000 cells per well. After $24 \mathrm{~h}$, culture medium was replaced with osteogenic induction medium consisting of growth medium supplemented with $252.39 \mu \mathrm{ML}(+)$-ascorbic acid sodium salt, $10 \mathrm{mM} \beta$-glycerophosphate, and $100 \mathrm{nM}$ dexamethasone. The medium was changed every $48 \mathrm{~h}$. Mineral deposition was analyzed using alizarin red S staining, as described below. Osteogenic marker gene expression was determined using quantitative real-time polymerase chain reaction, as described below. To test involvement of FGF signaling, in some experiments, SHEDs were pretreated with an FGFR inhibitor (SU5402) $30 \mathrm{~min}$ prior to bFGF exposure and cells were maintained in osteogenic induction medium supplemented with bFGF and SU5402 for the length of the experiment.

\section{Adipogenic induction}

Cells were seeded in 24-well plates at a density of 12,500 cells per well. Adipogenic induction medium consisted of growth medium supplemented with $0.1 \mathrm{mg} / \mathrm{mL}$ insulin, $1 \mathrm{mM}$ dexamethasone, $1 \mathrm{mM}$ isobutylmethylxanthine (IBMX), and $0.2 \mathrm{mM}$ indomethacin. The medium was changed every $72 \mathrm{~h}$. Oil Red O staining was performed to evaluate intracellular lipid accumulation according to a previously published protocol [2].

\section{Alkaline phosphatase activity (ALP) assay}

Cells were lysed in an alkaline lysis buffer. The samples were then incubated with $p$-nitrophenol phosphate solution $(2 \mathrm{mg} / \mathrm{mL}$, Invitrogen, USA). After $15 \mathrm{~min}$, the reaction was stopped by the addition of $50 \mathrm{mM} \mathrm{NaOH}$. The absorbance was measured at $410 \mathrm{~nm}$. Total protein was evaluated using a bicinchoninic acid (BCA) assay (Thermo Scientific, USA). ALP activity was calculated and normalized to the amount of total protein.

\section{Alizarin red S staining}

Alizarin red S staining was employed to determine calcium deposition in culture [20]. Cells were fixed with cold methanol for $10 \mathrm{~min}$ and washed with deionized water. Subsequently, cells were incubated with $1 \%$ alizarin red $S$ solution for $3 \mathrm{~min}$ at room temperature under gentle agitation. Cells were then washed with deionized water to remove excess staining. Precipitated dye was solubilized in $10 \% \mathrm{w} / v$ cetylpyridinium chloride solution, and the absorbance was measured at $570 \mathrm{~nm}$.

\section{Quantitative polymerase chain reaction (QPCR)}

RNA isolation was performed using RiboEx total RNA isolation solution (GeneAll, Seoul, South Korea). Complimentary DNA (cDNA) was synthesized from RNA using reverse transcriptase ImPromII kit (Promega, Madison, WI, USA). QPCR was performed using FastStart Essential DNA Green Master kit (Roche Diagnostic, USA) on the MiniOpticon real-time PCR system (Bio-Rad, USA). Target gene expression values were normalized to $18 \mathrm{~S}$ expression values and further normalized 
to controls. Oligonucleotide sequences are listed in Additional file 1: Table S1.

\section{Phosphate and pyrophosphate assay}

After osteo/odontogenic differentiation, the culture medium was collected and analyzed using the EnzChek ${ }^{\circ}$ Phosphate assay kit (Molecular PROBES, Oregon, USA) for quantitative analysis of $\mathrm{P}_{\mathrm{i}}$ and the EnzChek Pyrophosphate assay kit (Molecular PROBES, Oregon, USA) for detecting free $\mathrm{PP}_{\mathrm{i}}$ following the manufacturer's protocol. Absorbance was measured at $360 \mathrm{~nm}$.

\section{Statistical analyses}

Each experiment was performed using cells from at least four different donors. The Mann-Whitney $U$ test was employed for comparisons of two groups. For comparison of three or more groups, the Kruskal-Wallis test was performed, followed by pairwise comparison with type I error correction. All statistical analyses were performed using Prism 7 (GraphPad Software, CA, USA). Statistical significance was indicated by $p<0.05$.

\section{Results}

SHED cell isolation and characterization

Cells were harvested from pulp chambers of the extracted primary teeth. Expression of mesenchymal and hematopoietic stem cell surface markers was evaluated using flow cytometry. Consistent with expectations for SHEDs, the isolated cells expressed MSC markers, CD44, CD90, and CD105 (Fig. 1a-c), but lacked expression of hematopoietic stem cell marker, CD45 (Fig. 1d). The percentage of cells expressing CD44, CD90, and CD105 was over 95\%, 99\%, and 92\%, respectively (Fig. 1e). In contrast, only $1 \%$ were CD45-expressing cells. Significant upregulation of $A L P L$ and bone $\gamma$-carboxyglutamate protein (BGLAP) mRNA expression was observed after osteo/odontogenic induction for 7 days (Fig. 1f), and after 14 days, a marked increase of mineral deposition was evident (Fig. 1g). Upregulation of adipogenic markers, lipoprotein lipase $(L P L)$ and peroxisome proliferator-activated receptor $\gamma(P P A R \gamma)$, was observed after adipogenic induction for 8 days (Fig. 1h), and intracellular lipid accumulation was subsequently observed after 16 days (Fig. 1i). This combined evidence of MSC markers and multipotent differentiation ability

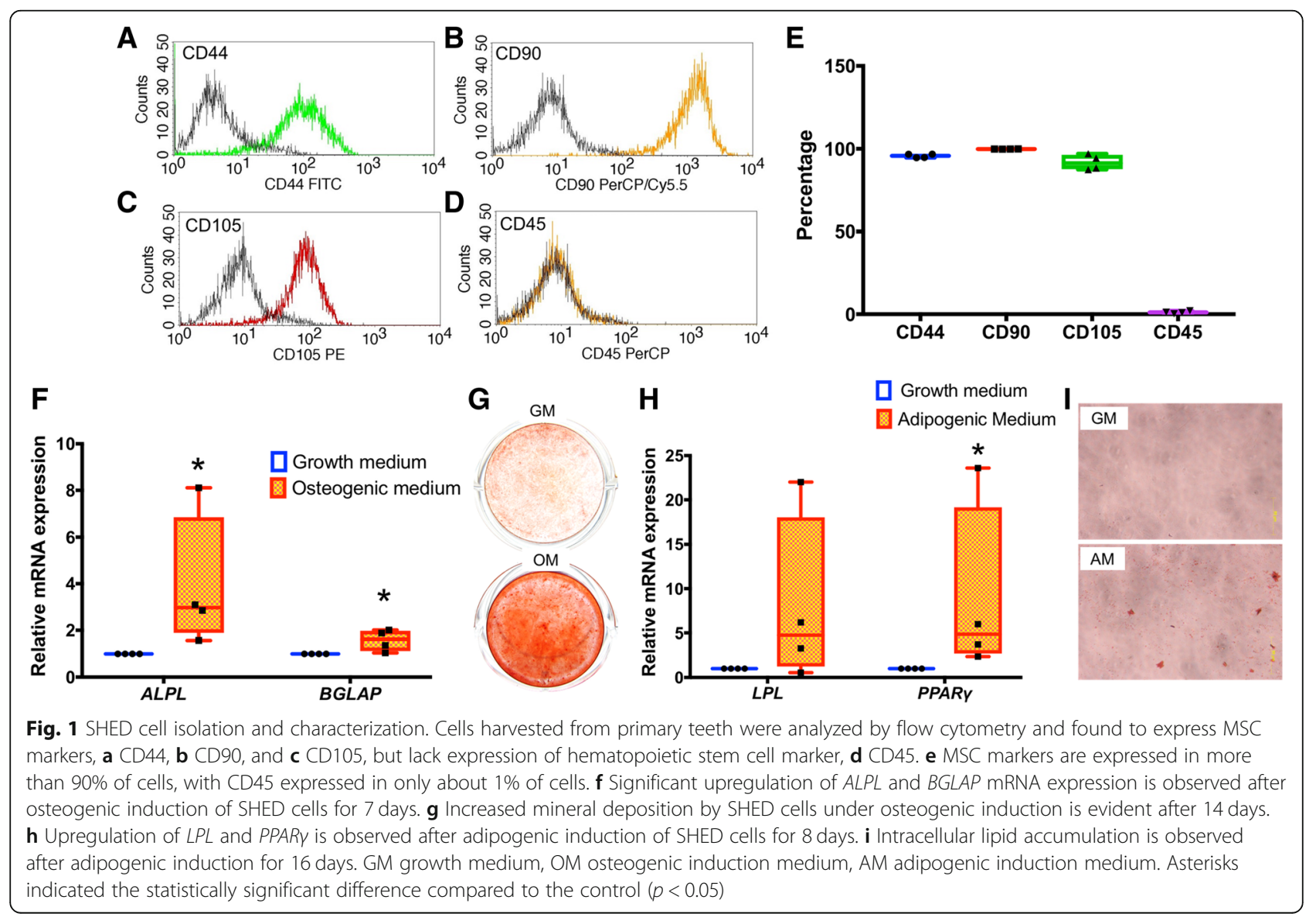


confirms the MSC-like characteristics of the isolated SHED cells.

\section{bFGF inhibits in vitro mineralization and alters osteo/ odontogenic gene expression in SHEDs}

During osteo/odontogenic induction over 14 days, bFGF mRNA levels were reduced in a time-dependent manner until they were decreased by about 50\% $(p<0.05)$ (Fig. 2a). Addition of $10 \mathrm{ng} / \mathrm{mL}$ bFGF to odontogenic induction medium led to the significant attenuation of mineral deposition at 14 days $(p<0.01)$ (Fig. 2b, c). This observation correlated with reduced ALP enzymatic activity in the bFGF-treated group after osteo/odontogenic induction for 7 days (Fig. 2d). Based on effects of bFGF on in vitro mineralization and ALP, we further investigated effects on genes associated with osteo/odontogenic differentiation and mineralization (Fig. 2e-j). bFGF treatment reduced mRNA expression of transcription factor, Runt-related transcription factor 2 (RUNX2), on day $1(40 \% ; p<0.05)$, but did not affect OSX expression (Fig. 2e, f). bFGF decreased COL1A1 mRNA (by 40$50 \% ; p<0.05$ ) on all days (Fig. $2 \mathrm{~g}$ ) and BGLAP (by $40 \%$; $p<0.05$ ) on day 3 (Fig. $2 \mathrm{~h}$ ), but did not affect expression of $S P P 1$ or DMP1 (Fig. 2i, j).

\section{bFGF alters expression of phosphate/pyrophosphate regulatory genes in SHEDs}

Experiments above confirmed bFGF regulates mineralization, ALP, and osteo/odontogenic genes in SHEDs. We next sought to determine if bFGF regulates expression of $\mathrm{P}_{\mathrm{i}} / \mathrm{PP}_{\mathrm{i}}$ regulatory genes, including $A L P L$, $A N K H, E N P P 1$, and the sodium- $\mathrm{P}_{\mathrm{i}}$ transporter, solute carrier family 20 member 1 (SLC20A1), during osteo/ odontogenic differentiation in SHEDs. Examination of

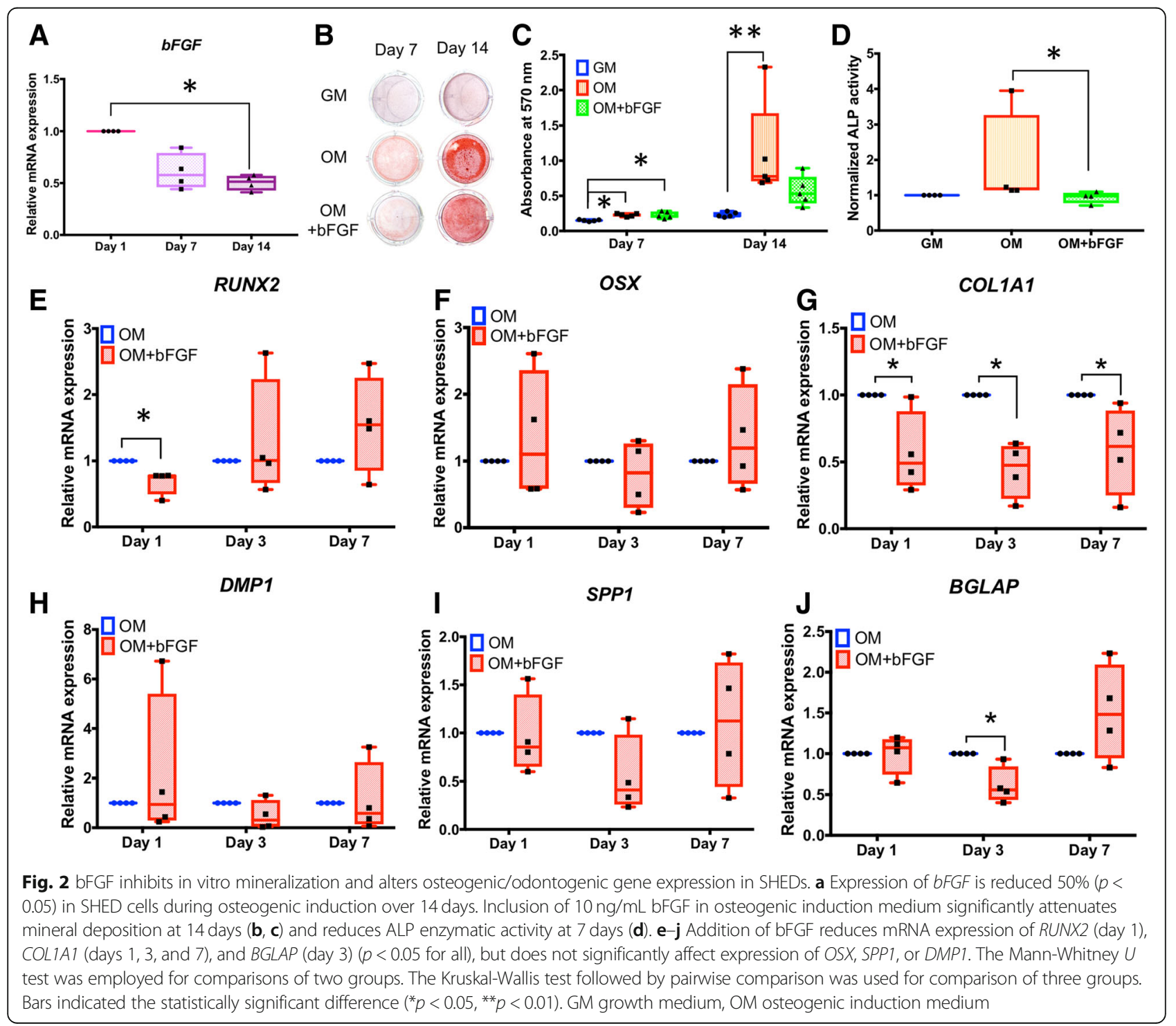


mRNA levels over 14 days of osteo/odontogenic differentiation demonstrated that $A L P L$ was upregulated at day 7 (3-fold; $p<0.05$ ) (Fig. 3a), while expression of $A N K H$ tended towards decrease and ENPP1 and SLC20A1 tended towards increase, though these changes were not significant within the parameters of these experiments (Fig. 3b-d).

The influence of bFGF on $\mathrm{P}_{\mathrm{i}} / \mathrm{PP}_{\mathrm{i}}$ regulatory gene expression was determined in osteogenic induction medium. bFGF treatment significantly inhibited $A L P L$ mRNA expression on days 3 and 7 after (by $50 \%$ or more; $p<0.05$ ) (Fig. 3e). Significant upregulation of $A N K H$ mRNA was observed on all days (between 50 and $100 \%$ increased; $p<0.05$ ) (Fig. 3f). bFGF did not alter ENPP1 expression during osteo/odontogenic induction (Fig. 3g) and induced SLC20A1 mRNA (more than $100 \% ; p<0.05$ ) on day 1 but not on later days (Fig. 3h).

SHEDs were pretreated with an FGFR inhibitor (SU5402) to confirm the involvement of bFGF signaling in modulation of $A L P L$ and $A N K H$ mRNA. SU5402 supplementation attenuated the influence of bFGF on both $A L P L$ and $A N K H$ mRNA expression, blocking the inhibitory effect of bFGF on ALPL (Fig. 3i) and preventing induction of $A N K H$ upregulation (Fig. 3j). Inhibition of endogenous bFGF function by addition of SU5402 to osteogenic medium (in the absence of exogenous bFGF addition) resulted in a significant increase of ALPL expression at 7 days (3-fold; $p<0.050$ ), but no significant regulation of $A N K H$ mRNA levels (Fig. 3k).

In time course experiments, cells were supplemented with bFGF and maintained in growth medium with expression assayed at 6,12 , and $24 \mathrm{~h}$. bFGF inhibition of $A L P L$ mRNA began between 12 and $24 \mathrm{~h}$ (about 70\% decrease; $p$ $<0.05$ ) (Fig. 4a). In contrast, the induction of $A N K H$ mRNA by bFGF was observed at 6,12 , and $24 \mathrm{~h}$ (approximately $50-75 \%$ increase; $p<0.05$ ) (Fig. 4b). Inclusion of FGFR inhibitor, SU5402, in growth medium for $24 \mathrm{~h}$ effectively abolished effects of bFGF on ALPL and ANKH expression (Fig. 4c, d). Inclusion of cycloheximide (CHX) in the media over $24 \mathrm{~h}$ also abolished effects of bFGF, strongly suggesting

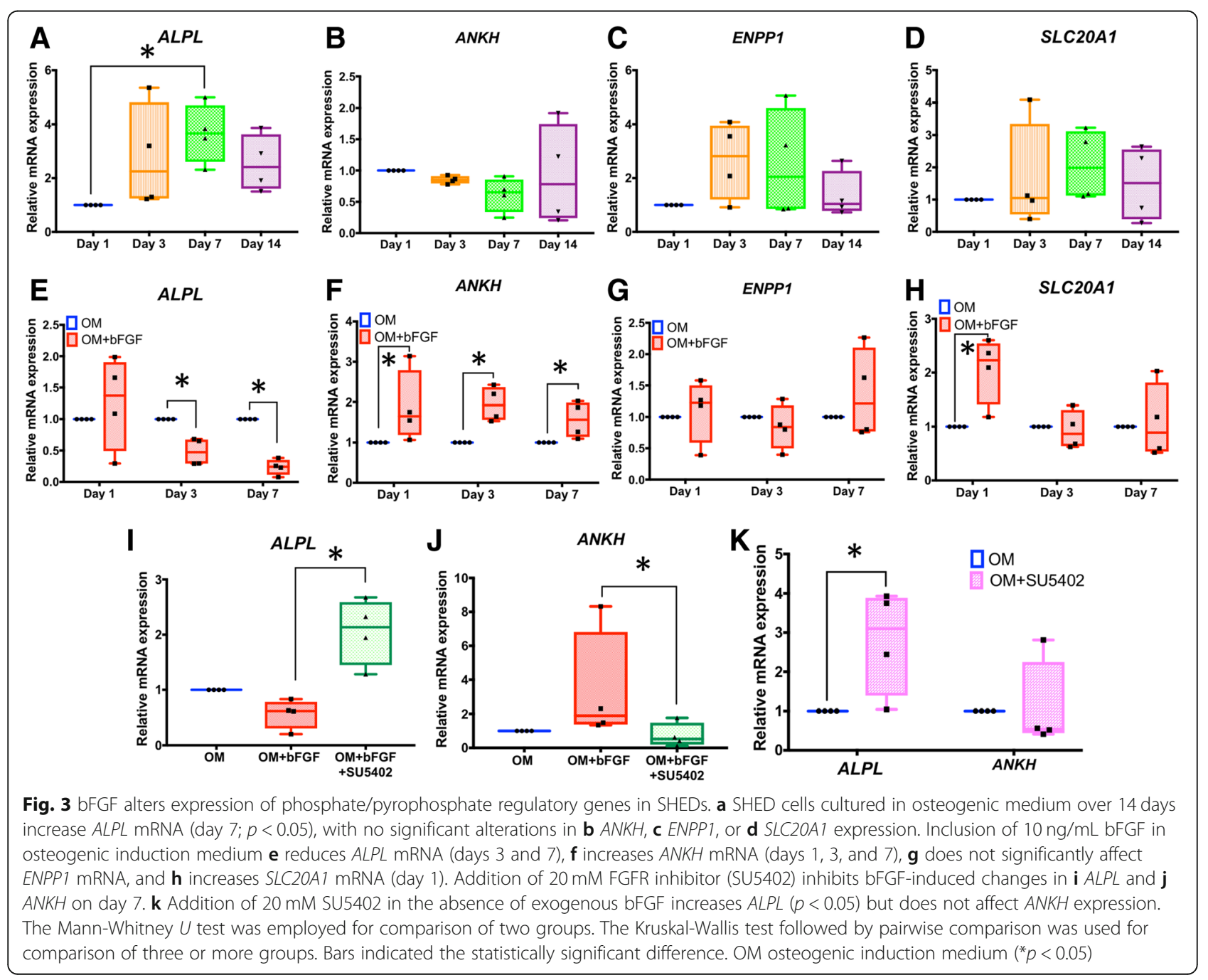



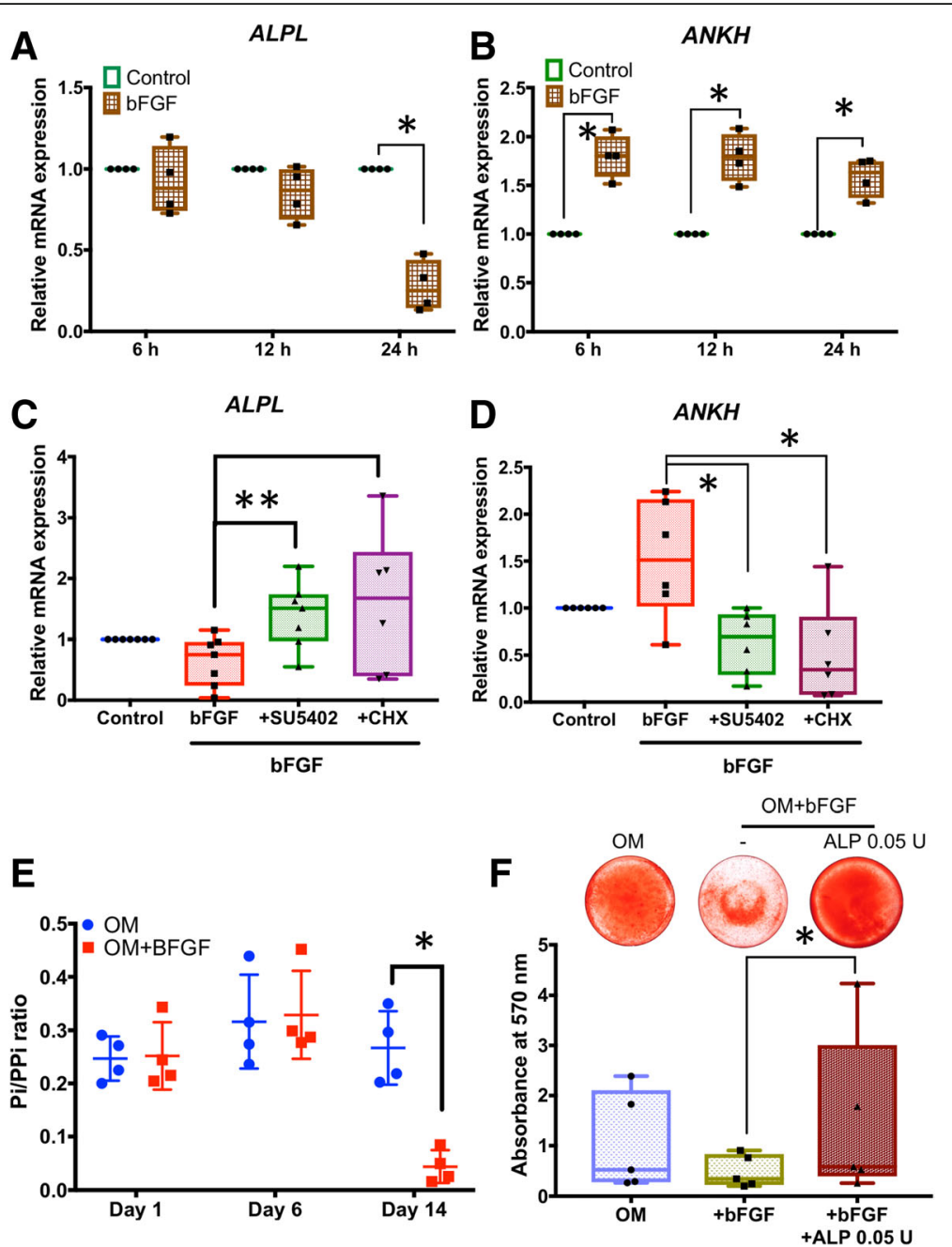

Fig. 4 Regulation of ALPL and ANKH expression by bFGF in SHEDs. Cells were maintained in normal growth medium in the presence or absence of $10 \mathrm{ng} / \mathrm{mL}$ bFGF for 6,12 , or $24 \mathrm{~h}$. a Addition of bFGF significantly inhibits ALPL mRNA by $24 \mathrm{~h}$. b The induction of ANKH mRNA by bFGF is observed at 6, 12, and $24 \mathrm{~h}$. c, d For both ALPL and ANKH, inclusion of $20 \mathrm{mM}$ FGFR inhibitor (SU5402) in growth medium abolishes effects of bFGF at $24 \mathrm{~h}$. Addition of $1 \mu \mathrm{g} / \mathrm{ml}$ cyclohexamide (CHX) inhibits effects of bFGF on ALPL and ANKH expression, suggesting that protein translation is required. e In culture medium collected from SHEDs on days 1, 6, and 14 after osteogenic induction, bFGF significantly reduces $P_{\mathrm{i}} / \mathrm{PP}_{\mathrm{i}}$ ratio by day 14. f Addition of $0.05 \mathrm{U}$ ALP rescues bFGF-attenuated ALP expression and mineral deposition in SHEDs. The Mann-Whitney $U$ test was employed for comparisons of two groups. The Kruskal-Wallis test followed by pairwise comparison was used for comparisons of three or more groups. Bars indicate statistically significant differences $\left({ }^{*} p<0.05,{ }^{* *} p<0.01\right)$. OM osteogenic induction medium

that protein translation is required as an intermediate step for the effects of bFGF on ALPL and ANKH (Fig. 4c, d).

Culture medium collected on days 1,6 , and 14 after osteo/odontogenic induction revealed bFGF significantly reduced $\mathrm{P}_{\mathrm{i}} / \mathrm{PP}_{\mathrm{i}}$ ratio by day 14 (by about $80 \% ; p<0.05$ ) (Fig. 4e), confirming a functional effect from reduced $A L P L$ and increased ANKH expression. Addition of $0.05 \mathrm{U}$ ALP rescued bFGF-attenuated mineral deposition (Fig. 4f).

\section{Inorganic phosphate and pyrophosphate regulate mineralization by SHEDs}

Effects of exogenous $\mathrm{PP}_{\mathrm{i}}$ on osteoblast and cementoblast mineralization in vitro have been reported [12, 21]; however, to our knowledge, $\mathrm{PP}_{\mathrm{i}}$ has not been tested on stem cells, or more specifically on SHEDs. Addition of $10 \mu \mathrm{M} \mathrm{PP} \mathrm{P}_{\mathrm{i}}$ to osteogenic induction medium of SHEDs nearly completely inhibited mineral deposition by 14 days (Fig. 5a, b). At 7 days, inclusion of $\mathrm{PP}_{\mathrm{i}}$ increased COL1A1 (4-fold; $p<0.05$ ) and ANKH (about 2-fold; $p<$ 0.05 ), but did not significantly affect a number of other genes associated with mineralization and $\mathrm{P}_{\mathrm{i}} / \mathrm{PP}_{\mathrm{i}}$ regulation, compared to untreated controls (Fig. $5 \mathrm{c}-\mathrm{l}$ ).

Effects of exogenous $\mathrm{P}_{\mathrm{i}}$ on osteoblast, cementoblast, and odontoblast mineralization and expression in vitro have been extensively studied [22-25], and experiments investigating effects of $P_{i}$ on various types of stem cells have been 

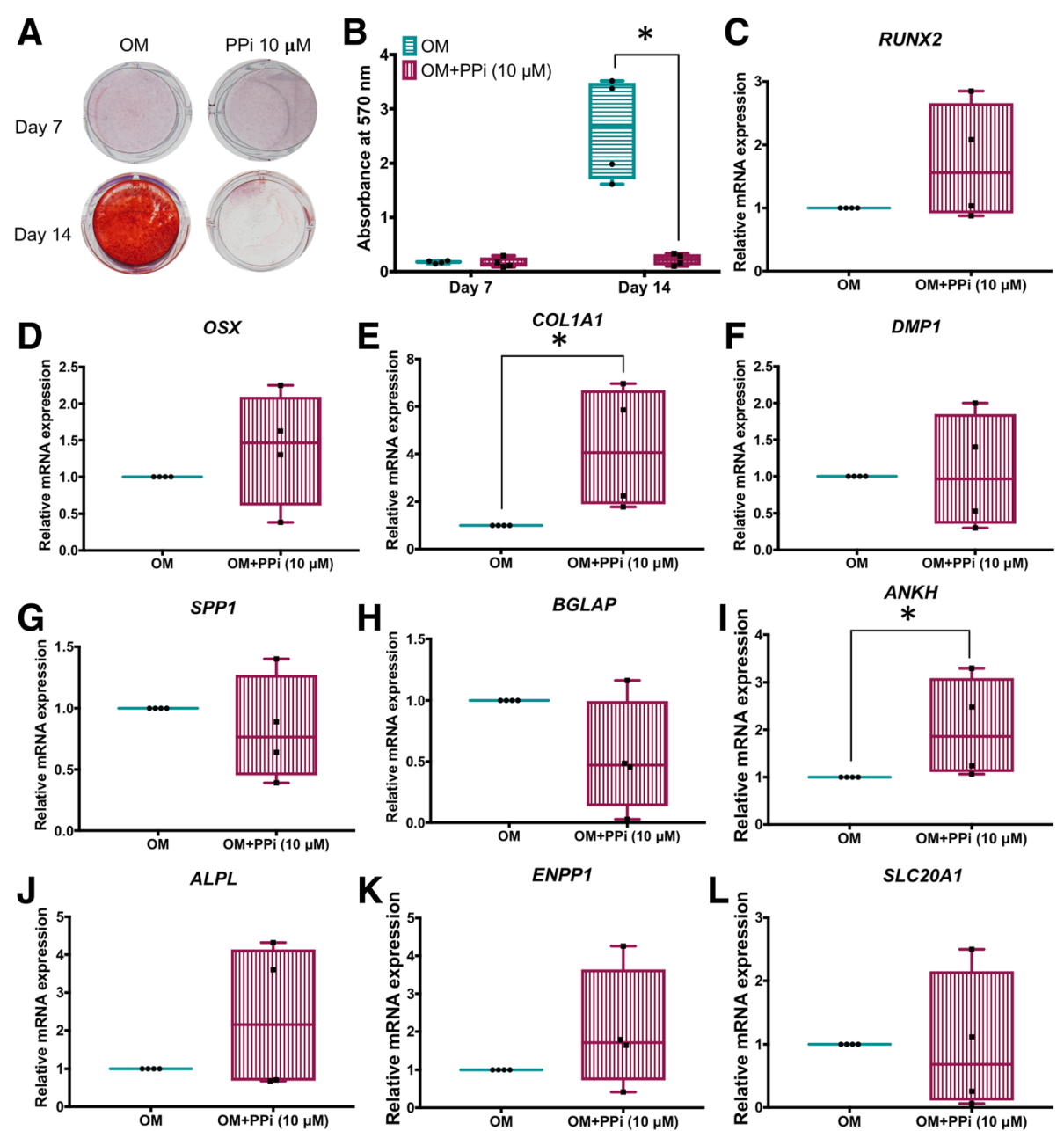

Fig. $5 \mathrm{PP}_{\mathrm{i}}$ regulates mineralization and gene expression in SHEDs. $\mathbf{a}, \mathbf{b}$ Addition of $10 \mu \mathrm{M} \mathrm{PP}_{\mathrm{i}}$ to osteogenic induction medium of SHED cells nearly completely inhibits mineral deposition by 14 days. c-I At 7 days, inclusion of $\mathrm{PP}_{\mathrm{i}}$ increases COL1A1 $(p<0.05)$ and ANKH $(p<0.05)$, but does not significantly affect other genes associated with mineralization and $\mathrm{P}_{\mathrm{i}} / \mathrm{PP}_{\mathrm{i}}$ regulation, compared to untreated controls. The Mann-Whitney $U$ test was employed for comparisons of two groups, and bars indicated the statistically significant difference $\left({ }^{*} p<0.05\right)$. OM osteogenic induction medium

reported [26, 27]. However, to our knowledge, this relationship has not been explored in SHEDs or other dental stem cells. Addition of $5 \mathrm{mM} \mathrm{P} \mathrm{P}_{\mathrm{i}}$ to osteogenic medium significantly increased mineral deposition by SHEDs at both days 7 and 14 (about 3- and 2-fold, respectively; $p<0.05$ for both) (Fig. 6a, b). At 7 days, inclusion of $P_{i}$ significantly induced OSX (10-fold), DMP1 (25-fold), SPP1 (50-fold), and $A N K H$ (4-fold) mRNA ( $p<0.05$ for all); however, other genes were unaffected (Fig. $6 \mathrm{c}-\mathrm{l}$ ).

From the above experiments, it was not clear whether $P_{i}$ or $\mathrm{PP}_{\mathrm{i}}$ was acting early or late to influence cell mineralization in the 14-day experiment. Therefore, the effect of duration of $\mathrm{P}_{\mathrm{i}}$ or $\mathrm{PP}_{\mathrm{i}}$ treatment was investigated. Continuous administration of $5 \mathrm{mM} \mathrm{P} \mathrm{P}_{\mathrm{i}}$ or $10 \mu \mathrm{MPP}$ in osteogenic medium served as the positive control, no added $\mathrm{P}_{\mathrm{i}}$ or $\mathrm{PP}_{\mathrm{i}}$ served as negative control, and conditions $\mathrm{A}, \mathrm{B}$, and $\mathrm{C}$ incorporated shorterterm $\mathrm{P}_{\mathrm{i}}$ or $\mathrm{PP}_{\mathrm{i}}$ treatments of 1,3 , or 7 days, respectively, followed by completion of the experiment in osteogenic medium (Fig. 7a). Continuous treatment of SHEDs with $\mathrm{P}_{\mathrm{i}}$ or $\mathrm{PP}_{\mathrm{i}}$ resulted in significantly increased (nearly 3-fold; $p<0.05$ ) or decreased (20-fold; $p<0.05$ ) mineral deposition, respectively (Fig. $7 \mathrm{~b}-\mathrm{e}$ ). Cells under condition A showed no significant difference in mineralization (Fig. 7b). Cells under condition $\mathrm{B}$ exhibited $\mathrm{PP}_{\mathrm{i}}$-mediated inhibition of mineralization by 3 days (Fig. 7c). Lastly, cells under condition $\mathrm{C}$ showed increased mineralization from $\mathrm{P}_{\mathrm{i}}$ treatment (more than 2-fold; $p<0.05$ ), while those receiving $\mathrm{PP}_{\mathrm{i}}$ treatment significantly reduced mineral deposition (Fig. 7d). These results within the first 7 days suggest that the supplementation of exogenous $\mathrm{P}_{\mathrm{i}}$ and $\mathrm{PP}_{\mathrm{i}}$ not only influences the precipitation and growth of mineral crystals, but may also affect intracellular mechanism(s).

\section{Discussion}

For the first time, we report effects of bFGF on regulation of $\mathrm{P}_{\mathrm{i}} / \mathrm{PP}_{\mathrm{i}}$ and mineralization in SHEDs. Addition of 

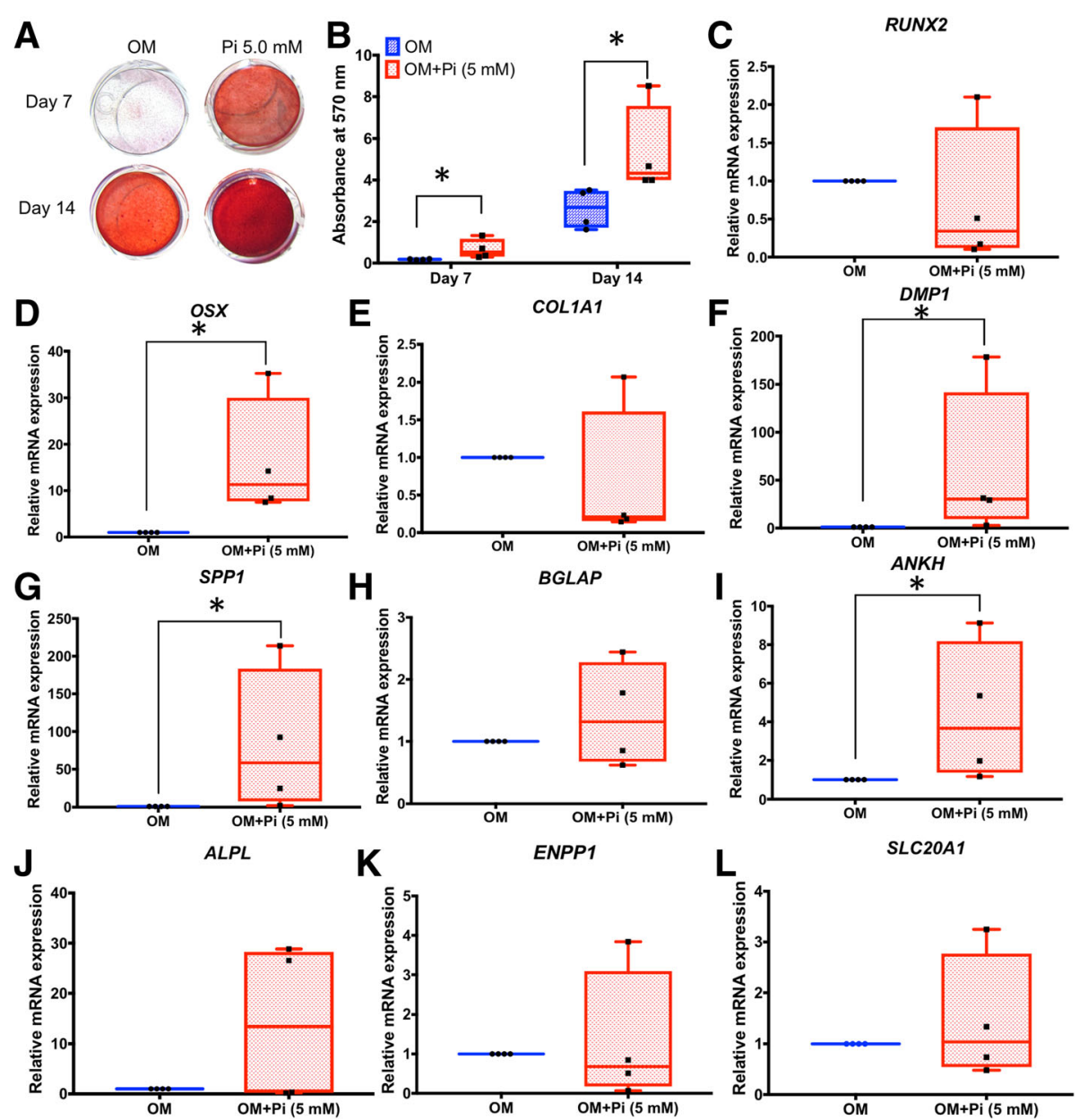

Fig. $6 P_{\mathrm{i}}$ regulates mineralization and gene expression in SHEDs. a, b Addition of $5 \mathrm{mM} \mathrm{P}$ to osteogenic induction medium of SHED cells increases mineral deposition at 7 and 14 days. $\mathbf{c}-I$ At 7 days, inclusion of $\mathrm{P}_{\mathrm{i}}$ increases OSX, DMP1, SPP1, and ANKH ( $p<0.05$ for all), but does not significantly affect other genes associated with mineralization and $\mathrm{P}_{\mathrm{i}} / \mathrm{PP}_{\mathrm{i}}$ regulation, compared to untreated controls. The Mann-Whitney $U$ test was employed for comparisons of two groups, and bars indicated the statistically significant difference $\left({ }^{*} p<0.05\right)$. OM osteogenic induction medium

bFGF to SHEDs during in vitro osteo/odontogenic differentiation decreased ALPL mRNA expression and ALP enzyme activity, increased $A N K H$ mRNA, and decreased $\mathrm{P}_{\mathrm{i}} / \mathrm{PP}_{\mathrm{i}}$ ratio and mineral deposition. Effects of bFGF on $A L P L$ and $A N K H$ mRNA expression were detected within $24 \mathrm{~h}$ and required FGFR signaling and protein synthesis. Addition of exogenous $\mathrm{PP}_{\mathrm{i}}$ inhibited mineralization and increased $A N K H, C O L 1 A 1$, and SPP1 mRNA, while addition of exogenous $P_{i}$ increased mineralization and increased OSX, ANKH, SPP1, and DMP1 mRNA. These effects of $\mathrm{PP}_{\mathrm{i}}$ and $\mathrm{P}_{\mathrm{i}}$ on mineralization could be replicated by short-term 3 - and 7-day treatments, suggesting early signaling effects in addition to physical-chemical modulation of mineral deposition. This study reveals the effects of $b F G F$ on $\mathrm{P}_{\mathrm{i}} / \mathrm{PP}_{\mathrm{i}}$ regulators in SHEDs and implicates these factors in how bFGF directs osteo/odontogenic differentiation and mineralization by these cells.
Regulation by bFGF of osteo/odontogenic markers and mineralization in SHED cells

Previous studies demonstrated that bFGF inhibited mineralization in SHEDs and DPSCs $[1,9]$. Here, we confirmed this effect of bFGF on mineralization in SHEDs and extended understanding of the underlying mechanisms by examining the influence of bFGF on other osteo/odontogenic markers and $\mathrm{P}_{\mathrm{i}} / \mathrm{PP}_{\mathrm{i}}$ regulators. Type 1 collagen, encoded by COL1A1 and COL1A2 genes, composes $90 \%$ of the extracellular matrix (ECM) of the bone, dentin, and cementum. bFGF significantly inhibited COL1A1 expression during osteo/odontogenic differentiation on days 1,3 , and 7 . It has been shown that bFGF suppresses COL1 and COL3 while enhancing mRNA expression of matrix metalloproteinases $M M P 1$ and $M M P 2$ in human periodontal ligament (PDL) cells, suggesting a catabolic influence of bFGF on ECM regulation [28]. Similarly, collagen synthesis was reduced by 


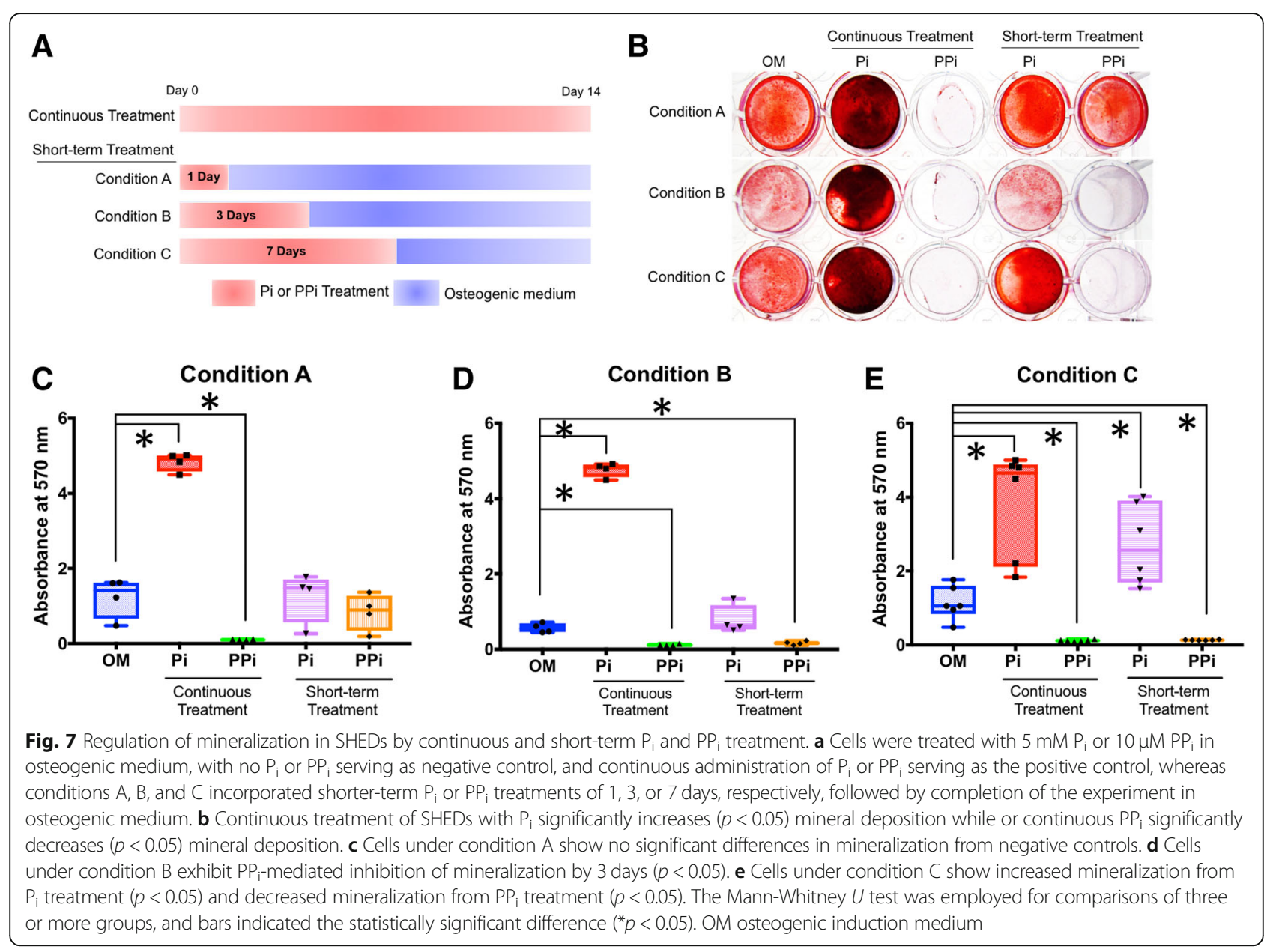

bFGF treatment in rat hair dermal papilla cells [29]. Hence, the bFGF-induced reduction of COL1A1 expression could be beneficial in terms of scar formation during wound healing. On the contrary, in rabbit chondrocytes, bFGF did not influence COL1A1 mRNA levels but suppressed COL2 mRNA expression [30]. Tenocytes overexpressing bFGF increased COL1 and COL3 expression.

We demonstrated that bFGF inhibits RUNX2 and BGLAP mRNA expression on days 1 and 3, respectively. RUNX2 serves a master transcription factor regulating osteo/odontogenic differentiation and function, upstream of numerous key genes [31, 32]. BGLAP encodes $\mathrm{OCN}$, an extracellular matrix protein found in the bone, dentin, and cementum and posited to regulate mineralization as well as perform wider endocrine functions [33, 34]. Previous publications implicated bFGF inhibition of osteo/odontogenic differentiation of SHEDs in part via reduction of RUNX2 and BGLAP mRNA [8]. Similarly, studies on stem cells from apical papilla (SCAP) showed that bFGF treatment during osteo/odontogenic induction decreased BGLAP mRNA levels at early but not late time points [35]. In PDL cells, bFGF inhibited mineralization when added to osteogenic medium, but with no apparent regulation of $R U N X 2$ or $B G L A P$ expression, suggesting alternative mechanisms [36]. However, bFGF induced RUNX2 expression in human periodontal ligament cells which are maintained in growth medium [36]. In mouse osteoblasts, bFGF attenuated RUNX2-induced Alpl expression [37]. The influence of bFGF on RUNX2 and OCN at specific time points during osteo/odontogenic induction of SHEDs and other cells requires further investigation.

These collected data concerning effects of bFGF on COL1A1, RUNX2, and BGLAP suggest cell-type-specific responses to bFGF. The reduction of all three of these osteo/odontogenic markers concomitant with decreased mineral deposition supports a link to attenuation of mineralization; however, additional studies are warranted to explore these relationships further.

\section{Effect of bFGF on $\mathrm{P}_{\mathrm{i}}$ and $\mathrm{PP}$ regulators in SHED cells}

During osteo/odontogenic differentiation, SHEDs upregulated $A L P L$ expression early, while $A N K H, E N P P 1$, and SLC20A1 mRNA levels were not markedly changed during the differentiation period assayed here. Alpl was 
induced early in OCCM.30 murine cementoblasts, and Ank, Enpp1, Spp1, and Dmp1 mRNA increased at later times after mineral deposition [38]. In MC3T3.E1 murine pre-osteoblasts, bFGF induced Enpp 1 and Ank but inhibited Alpl mRNA expression [19]. In MLO-Y4 murine osteocyte-like cells, bFGF upregulated Ank, Enpp1, Slc20a1, and Dmp1 [39]. Conversely, we showed here that bFGF suppressed $A L P L$ but induced $A N K H$ expression in SHEDs, while ENPP1 expression was not markedly changed by exposure to bFGF. These changes were blocked by addition of an FGFR inhibitor, confirming the requirement of FGF signaling. In addition, the effect of bFGF on ALPL and $A N K H$ expression was attenuated by protein synthesis inhibitor, suggesting the involvement of intermediate factors in the regulation process. Ultimately, the consequence of bFGF-reduced $A L P L$ and increased $A N K H$ in SHEDs was borne out by significantly decreased $\mathrm{P}_{\mathrm{i}} / \mathrm{PP}_{\mathrm{i}}$ ratio, an alteration that likely contributed to reduced mineralization in vitro and would be anticipated to have a potent effect to inhibit ECM mineralization.

Based on inhibition of mineralization and changes in $\mathrm{P}_{\mathrm{i}} / \mathrm{PP}_{\mathrm{i}}$ regulatory genes in response to bFGF, we explored direct effects of exogenous $\mathrm{PP}_{\mathrm{i}}$ or $\mathrm{P}_{\mathrm{i}}$ on SHEDs during osteo/odontogenic differentiation. Addition of exogenous $\mathrm{PP}_{\mathrm{i}}$ inhibited mineralization and significantly upregulated COL1A1 and $A N K H$ expression in SHEDs. In OCCM.30 cementoblasts, $10-100 \mu \mathrm{M} \mathrm{PP}_{\mathrm{i}}$ decreased mineral deposition, and removal of $\mathrm{PP}_{\mathrm{i}}$ from culture medium during early stages allowed mineral deposition to proceed as normal, suggesting a primarily physicochemical effect on mineral deposition by these cells [12]. In contrast, a dose of $2.5 \mu \mathrm{M} \mathrm{PP}$ increased Alpl and Ank and decreased Enpp1 in MC3T3.E1 pre-osteoblasts, implicating direct signaling effects [21]. We documented that withdrawal of $\mathrm{PP}_{\mathrm{i}}$ from medium after 1 day allowed SHEDs to mineralize similar to untreated controls; however, $\mathrm{PP}_{\mathrm{i}}$ withdrawal after days 3 or 7 did not reverse the inhibitory effect of $\mathrm{PP}_{\mathrm{i}}$ on mineralization. Because SHEDs largely mineralize between 7 and 14 days in osteogenic medium, these results suggest that $\mathrm{PP}_{\mathrm{i}}$ not only inhibits mineral precipitation and growth, but may also regulate cells through additional signaling mechanisms, a hypothesis that requires further investigation. In Alpl knockout $\left(\mathrm{Alpl}^{-/-}\right)$mice, a model for the hereditary error-in-metabolism, hypophosphatasia (HPP), loss of TNAP function increases $\mathrm{PP}_{\mathrm{i}}$ and prevents mineralization in the bones and teeth. Severely hypomineralized dentin in $\mathrm{Alpl}^{-/-}$mice was accompanied by loss of expression of Bglap and dentin sialophosphoprotein (Dspp) mRNA by odontoblasts [40], supporting a connection between $\mathrm{PP}_{\mathrm{i}}$, mineralization, and altered expression in skeletal/dental cells in vivo.

Addition of $5 \mathrm{mM} \mathrm{P} \mathrm{P}_{\mathrm{i}}$ significantly increased OSX, $D M P 1, S P P 1$, and $A N K H$ mRNA in SHEDs. $\mathrm{P}_{\mathrm{i}}$ is well established as a potent signal in osteoblasts, cementoblasts, and odontoblasts [22-25, 41]. Spp1/OPN was first identified as a target for $\mathrm{P}_{\mathrm{i}}$ signaling in MC3T3.E1 murine pre-osteoblasts, where extracellular signal-regulated kinases (ERK) $1 / 2$ and protein kinase $C$ (PKC) pathways were implicated in its transcription [25, 41]. Subsequently, $P_{i}$ was found to regulate numerous genes in osteoblasts [41-43]. In OCCM.30 cementoblasts, $P_{i}$ also induced Spp1/OPN, possibly through a glucocorticoid receptor in the promoter region $[22,44]$. OPN is a multifunctional ECM protein involved in cell migration, attachment, differentiation, and also a negative regulator of mineralization proposed to be involved in pathological hypomineralization of dentin in diseases such as HPP and X-linked hypophosphatemia (XLH) [40, 4547]. Genetic ablation of OPN in $S p p 1^{-/-}$mice resulted in increased mineral content in the bones, increased cortical and trabecular bone parameters in femurs and tibias, and increased dentin and alveolar bone [48-50]. Interestingly, $S p p 1^{-/-}$mice featured defective reparative dentin formation, suggesting the protein is necessary for pulpo-dentinal healing [51].

DMP1 is an ECM protein closely related to OPN that is expressed by odontoblasts, osteoblasts, and osteocytes. $\mathrm{P}_{\mathrm{i}}$ induction of Dmp1/DMP1 was previously documented in OCCM.30 murine cementoblasts and human PDL fibroblasts [12, 52]. DMP1 is critical for dentin formation and periodontal development. Dmp knockout $\left(D m p 1^{-/-}\right)$mice exhibit a dentinogenesis imperfecta-like phenotype including thin and hypomineralized dentin and an enlarged pulp cavity in the molars [53]. Additionally, loss-of-function of DMP1 is responsible for autosomal recessive hypophosphatemic rickets, an endocrine disorder marked by low circulating $\mathrm{P}_{\mathrm{i}}$ and severe hypomineralization of the bones and teeth [54].

OSX is a transcription factor directing osteoblast and odontoblast differentiation $[55,56]$. The upregulation of OSX in SHEDs by $\mathrm{P}_{\mathrm{i}}$ observed in the present study paralleled $\mathrm{P}_{\mathrm{i}}$ induced Osx expression in rat kidney fibroblast and human vascular smooth muscle cells $[57,58]$. In those cells, $\mathrm{P}_{\mathrm{i}}$ induced upregulation of Osx occurred via Akt1 and ERK signaling [57].

Addition of $\mathrm{P}_{\mathrm{i}}$ to SHEDs increased expression of $A N K H$ mRNA. Induction of $A n k$ was also achieved by addition of $5 \mathrm{mM} \mathrm{P}_{\mathrm{i}}$ to OCCM.30 murine cementoblast cells, hypothesized to be a response to pro-mineralization conditions and a sort of negative feedback to compensate the overabundance of extracellular $\mathrm{P}_{\mathrm{i}}$ and to balance $\mathrm{P}_{\mathrm{i}} / \mathrm{PP}_{\mathrm{i}}$ ratio, and regulate the pace of mineralization [22]. Loss of function of $A n k / A N K H$ leads to decreased $\mathrm{PP}_{\mathrm{i}}$ and increased and sometimes ectopic mineralization, and Ank mutant or knockout mice feature skeletal differences and massively increased acellular cementum [12, 14, 17, 59]. These potent effects of ANK/ANKH on mineralized tissue 
development in vivo justify further investigation of the interactions of bFGF, $A N K H, \mathrm{PP}_{\mathrm{i}}$, and mineralization in SHEDs.

\section{Influence of local $\mathrm{P}_{\mathrm{i}}$ and $\mathrm{PP}_{\mathrm{i}}$ regulation on tooth development and regeneration}

$\mathrm{P}_{\mathrm{i}}$ and $\mathrm{PP}_{\mathrm{i}}$ participate in tooth development and regeneration. Their roles were demonstrated by the investigation in knockout and mutated mouse models. Alpl mutation, resulting in increased local $\mathrm{PP}_{\mathrm{i}}$ concentrations, causes delayed tooth eruption, aplasia or hypoplasia of cementum, and defective insertion of Sharpey's fibers [10, 60]. Conversely, mice lacking Ank or Enpp1 function exhibited hypercementosis with otherwise normal dental and periodontal structure $[10,61]$. These data strongly support the significant role of local $\mathrm{P}_{\mathrm{i}} / \mathrm{PP}_{\mathrm{i}}$ ratio via regulation by TNAP, ANK/ANKH, and ENPP1, in directing tooth development and structural formation.

Besides the role of $\mathrm{P}_{\mathrm{i}} / \mathrm{PP}_{\mathrm{i}}$ in tooth development, modulation of this ratio has also been proposed as an alternative approach for regenerative treatment. TNAP immobilized fibrin scaffolds enhanced $P_{i}$ concentration and osteogenic differentiation in vitro as well as increased calvarial bone regeneration in vivo [62]. Local delivery of polyphosphate led to the increase alveolar bone regeneration around rat molars [63]. Studies of Ank knockout mice demonstrated that decreased $\mathrm{PP}_{\mathrm{i}}$ promoted more rapid and greater cementum regeneration in a periodontal defect model compared to wild-type mice [64], implying a role for $\mathrm{P}_{\mathrm{i}} / \mathrm{PP}_{\mathrm{i}}$ regulation in periodontal tissue regeneration. However, more work must indeed be done to understand the mechanism(s) and to develop treatment strategies in translational and clinical settings.

\section{Benefit of bFGF in future clinical applications}

The present study aimed to investigate regulatory mechanisms whereby bFGF affected SHED differentiation and mineralization. We concluded that continuous bFGF treatment of SHEDs inhibited mineral deposition, in part via regulation of genes controlling $\mathrm{P}_{\mathrm{i}} / \mathrm{PP}_{\mathrm{i}}$ metabolism. However, several reports demonstrated that bFGF pretreatment before osteogenic induction promoted osteogenic potential of various human stem/progenitor cells [65]. Our findings parallel those of Fakhry and colleagues, which indicated that continuous treatment of calvarial osteoblasts with bFGF inhibited osteogenic gene expression and mineralization, while short-term treatment of bFGF stimulated osteogenic differentiation [66]. Moreover, previous publications reported the beneficial utilization of bFGF in hard tissue formation through various approaches. Local application of bFGF enhanced dental implant stability and osseointegration in animal models $[67,68]$. In addition, bFGF has been utilized in alveolar bone and periodontal tissue regeneration, i.e., periodontal defect treatment and alveolar ridge preservation $[69,70]$. The anabolic effect of bFGF in vivo could result from the brief exposure of local cells to the released proteins, prompting osteogenic differentiation. In addition, bFGF regulates angiogenesis, cell migration, and cell proliferation [71, 72]. Hence, these processes could help to facilitate the healing and formation of hard tissue in vivo.

Another potential use of bFGF in clinical regenerative therapy would be to maintain stemness of stem and progenitor populations in vitro. It has been shown that mesenchymal stem cells isolated from dental tissues lose their stem cell properties and decline in proliferation during long-term culture in vitro [7]. Our previous reports revealed that continuous bFGF treatment in vitro promoted maintenance of stemness in dental tissue-derived mesenchymal stem cells $[1,2,7]$. The bFGF supplementation in long-term culture of SHEDs enhanced colony-forming unit ability and stem cell marker gene expression [7]. Hence, bFGF could be useful to amplify cell number while maintaining stem cell properties in vitro for future regenerative application of SHEDs.

\section{Conclusions}

This study reveals the effects of bFGF on osteogenic differentiation ability of SHEDs. In addition, it has been demonstrated that bFGF influences $\mathrm{P}_{\mathrm{i}} / \mathrm{PP}_{\mathrm{i}}$ regulators in SHEDs and implicates these factors in how bFGF directs osteo/odontogenic differentiation and mineralization by these cells.

\section{Additional file}

Additional file 1: Table S1. Primer sequences for QPCR. (DOCX $18 \mathrm{~kb}$ )

\section{Abbreviations}

Akt: Serine/threonine-specific protein kinase; ALP: Alkaline phosphatase; ALPL: Tissue-nonspecific alkaline phosphatase; ANKH: Progressive ankylosis protein; BCA: Bicinchoninic acid; bFGF: Basic fibroblast growth factor; BGLAP: Bone $\gamma$-carboxyglutamate protein; CD105: Cluster of differentiation 105; CD44: Cluster of differentiation 44; CD45: Cluster of differentiation 45; CD90: Cluster of differentiation 90; CDNA: Complimentary DNA;

CHX: Cycloheximide; COL1: Collagen type 1; COL12: Collagen type 2; COL1A1: Collagen type 1a1; COL1A2: Collagen type 1a2; COL3: Collagen type 3; DMP1: Dentin matrix protein 1; DPSCs: Dental pulp stem cells; Dspp: Dentin sialophosphoprotein; ECM: Extracellular matrix;

ENPP1: Ectonucleotide pyrophosphatase phosphodiesterase 1; ERK: Extracellular signal-regulated kinases; FGFR: Fibroblast growth factor receptor; HPP: Hypophosphatasia; IBMX: Isobutylmethylxanthine; LPL: Lipoprotein lipase; MMP: Matrix metalloproteinases; MSCs: Mesenchymal stem cells; NANOG: Nanog homeobox; $\mathrm{NaOH}$ : Sodium hydroxide;

OCCM.30: Murine cementoblast cell line; OCN: Osteocalcin; OCT4: POU class 5 homeobox 1; OPN: Osteopontin; OSX: Osterix; PDL: Periodontal ligament; $P_{i}$ : Inorganic phosphate; PKC: Protein kinase C; PPARY: Peroxisome proliferator-activated receptor $\gamma_{i}$ PP: Inorganic pyrophosphate; REX1: ZFP42 zinc finger protein; RUNX2: Runt-related transcription factor 2; SCAP: Stem cells from apical papilla; SHEDs: Stem cells isolated from human exfoliated deciduous teeth; SLC20A1: Solute carrier family 20 member 1; SPP1: Secreted 
phosphoprotein 1; SU5402: FGFR inhibitor; TNAP: Tissue-nonspecific alkaline phosphatase; XLH: X-linked hypophosphatemia

\section{Acknowledgements}

Authors thank to the Oral Biology Research Center for providing the research facilities. We appreciate the assistance from the Department of Pediatric Dentistry for sample collection.

\section{Funding}

This study was supported by the Chulalongkorn Academic Advancement Into Its 2nd Century Project. TO is supported by Thailand Research Fund (RSA6180019). NN is supported by the Ratchadapisek Sompote Fund for Postdoctoral Fellowship, Chulalongkorn University.

\section{Availability of data and materials}

Please contact the corresponding author for data requests.

\section{Authors' contributions}

NN contributed to the experimental design, data acquisition and analysis, and critical manuscript revision. WS contributed to the cell isolation from deciduous teeth, data interpretation, and critical manuscript revision. PP contributed to the data interpretation and critical manuscript revision. BF contributed to the experimental design, data interpretation, and critical manuscript revision. TO contributed to the study conception and experimental design, data analysis and interpretation, and manuscript preparation. All authors read and approved the final manuscript.

\section{Ethics approval and consent to participate}

The study was approved by Human Research Ethics Committee, Faculty of Dentistry, Chulalongkorn University (Approval number 2015-007). The procedure was performed according to the Declaration of Helsinki. Informed consent was obtained from parents.

\section{Consent for publication}

Not applicable.

\section{Competing interests}

The authors declare that they have no competing interests.

\section{Publisher's Note}

Springer Nature remains neutral with regard to jurisdictional claims in published maps and institutional affiliations.

\section{Author details}

${ }^{1}$ Center of Excellence for Regenerative Dentistry, Chulalongkorn University, Bangkok 10330, Thailand. 'Department of Pediatric Dentistry, Faculty of Dentistry, Chulalongkorn University, Bangkok 10330, Thailand. ${ }^{3}$ Department of Anatomy, Faculty of Dentistry, Chulalongkorn University, 34 Henri-Dunant Road, Bangkok 10330, Thailand. ' Division of Biosciences, College of Dentistry, The Ohio State University, Columbus, OH 43210, USA. ${ }^{5}$ Genomics and Precision Dentistry Research Unit, Chulalongkorn University, Bangkok 10330 Thailand.

Received: 9 October 2018 Revised: 12 November 2018 Accepted: 27 November 2018 Published online: 10 December 2018

\section{References}

1. Osathanon T, Nowwarote N, Pavasant P. Basic fibroblast growth factor inhibits mineralization but induces neuronal differentiation by human dental pulp stem cells through a FGFR and PLCgamma signaling pathway. J Cell Biochem. 2011;112:1807-16.

2. Nowwarote $N$, Sukarawan $W$, Pavasant $P$, Osathanon T. Basic fibroblast growth factor regulates REX1 expression via IL-6 in stem cells isolated from human exfoliated deciduous teeth. J Cell Biochem. 2017;118:1480-8.

3. Wang G, Zhang H, Zhao Y, Li J, Cai J, Wang P, et al. Noggin and bFGF cooperate to maintain the pluripotency of human embryonic stem cells in the absence of feeder layers. Biochem Biophys Res Commun. 2005; 330:934-42.

4. Ding VM, Ling L, Natarajan S, Yap MG, Cool SM, Choo AB. FGF-2 modulates Wnt signaling in undifferentiated hESC and iPS cells through activated PI3KGSK3beta signaling. J Cell Physiol. 2010;225:417-28.
5. Miura M, Gronthos S, Zhao M, Lu B, Fisher LW, Robey PG, et al. SHED: stem cells from human exfoliated deciduous teeth. Proc Natl Acad Sci U S A 2003; 100:5807-12

6. Nowwarote N, Pavasant P, Osathanon T. Role of endogenous basic fibroblast growth factor in stem cells isolated from human exfoliated deciduous teeth. Arch Oral Biol. 2015:60:408-15.

7. Sukarawan W, Nowwarote N, Kerdpon P, Pavasant P, Osathanon T. Effect of basic fibroblast growth factor on pluripotent marker expression and colony forming unit capacity of stem cells isolated from human exfoliated deciduous teeth. Odontology. 2014;102:160-6.

8. Li B, Qu C, Chen C, Liu Y, Akiyama K, Yang R, et al. Basic fibroblast growth factor inhibits osteogenic differentiation of stem cells from human exfoliated deciduous teeth through ERK signaling. Oral Dis. 2012;18:285-92.

9. Osathanon T, Nowwarote N, Manokawinchoke J, Pavasant P. bFGF and JAGGED1 regulate alkaline phosphatase expression and mineralization in dental tissue-derived mesenchymal stem cells. J Cell Biochem. 2013;114: 2551-61.

10. Foster BL, Tompkins KA, Rutherford RB, Zhang $H$, Chu EY, Fong $H$, et al. Phosphate: known and potential roles during development and regeneration of teeth and supporting structures. Birth Defects Res C Embryo Today. 2008:84:281-314.

11. Chang YL, Stanford CM, Keller JC. Calcium and phosphate supplementation promotes bone cell mineralization: implications for hydroxyapatite (HA)enhanced bone formation. J Biomed Mater Res. 2000:52:270-8.

12. Foster BL, Nagatomo KJ, Nociti FH Jr, Fong H, Dunn D, Tran AB, et al. Central role of pyrophosphate in acellular cementum formation. PLoS One. 2012;7:e38393

13. Foster BL, Kuss P, Yadav MC, Kolli TN, Narisawa S, Lukashova L, et al. Conditional Alpl ablation phenocopies dental defects of hypophosphatasia. J Dent Res. 2017:96:81-91.

14. Harmey D, Hessle L, Narisawa S, Johnson KA, Terkeltaub R, Millan JL. Concerted regulation of inorganic pyrophosphate and osteopontin by akp2 enpp1, and ank: an integrated model of the pathogenesis of mineralization disorders. Am J Pathol. 2004:164:1199-209.

15. Mackenzie NC, Zhu D, Milne EM, van 't Hof R, Martin A, Darryl Quarles L, et al. Altered bone development and an increase in FGF-23 expression in Enpp1(-/-) mice. PLoS One. 2012;7:e32177.

16. Dutra EH, Chen IP, Reichenberger EJ. Dental abnormalities in a mouse model for craniometaphyseal dysplasia. J Dent Res. 2013;92:173-9.

17. Ao M, Chavez MB, Chu EY, Hemstreet KC, Yin Y, Yadav MC, et al. Overlapping functions of bone sialoprotein and pyrophosphate regulators in directing cementogenesis. Bone. 2017;105:134-47.

18. Thumbigere-Math V, Alqadi A, Chalmers NI, Chavez MB, Chu EY, Collins MT, et al. Hypercementosis associated with ENPP1 mutations and GACl. J Dent Res. 2018:97:432-41.

19. Hatch NE, Nociti F, Swanson E, Bothwell M, Somerman M. FGF2 alters expression of the pyrophosphate/phosphate regulating proteins, $\mathrm{PC}-1$, ANK and TNAP, in the calvarial osteoblastic cell line, MC3T3E1(C4). Connect Tissue Res. 2005:46:184-92.

20. Nowwarote N, Osathanon T, Jitjaturunt $P$, Manopattanasoontorn S, Pavasant $P$. Asiaticoside induces type I collagen synthesis and osteogenic differentiation in human periodontal ligament cells. Phytother Res. 2013;27:457-62.

21. Addison WN, Azari F, Sorensen ES, Kaartinen MT, McKee MD. Pyrophosphate inhibits mineralization of osteoblast cultures by binding to mineral, upregulating osteopontin, and inhibiting alkaline phosphatase activity. J Biol Chem. 2007;282:15872-83.

22. Foster BL, Nociti FH Jr, Swanson EC, Matsa-Dunn D, Berry JE, Cupp CJ, et al. Regulation of cementoblast gene expression by inorganic phosphate in vitro. Calcif Tissue Int. 2006;78:103-12

23. Rutherford RB, Foster BL, Bammler T, Beyer RP, Sato S, Somerman MJ. Extracellular phosphate alters cementoblast gene expression. J Dent Res. 2006:85:505-9.

24. Chaudhary SC, Kuzynski M, Bottini M, Beniash E, Dokland T, Mobley CG, et al. Phosphate induces formation of matrix vesicles during odontoblastinitiated mineralization in vitro. Matrix Biol. 2016;52-54:284-300.

25. Beck GR Jr, Zerler B, Moran E. Phosphate is a specific signal for induction of osteopontin gene expression. Proc Natl Acad Sci U S A. 2000;97:8352-7.

26. Schack LM, Noack S, Winkler R, Wissmann G, Behrens P. Wellmann M, et al. The phosphate source influences gene expression and quality of mineralization during in vitro osteogenic differentiation of human mesenchymal stem cells. PLoS One. 2013;8:e65943. 
27. Liu YK, Lu QZ, Pei R, Ji HJ, Zhou GS, Zhao XL, et al. The effect of extracellular calcium and inorganic phosphate on the growth and osteogenic differentiation of mesenchymal stem cells in vitro: implication for bone tissue engineering. Biomed Mater. 2009;4:025004.

28. Silverio-Ruiz KG, Martinez AE, Garlet GP, Barbosa CF, Silva JS, Cicarelli RM, et al. Opposite effects of bFGF and TGF-beta on collagen metabolism by human periodontal ligament fibroblasts. Cytokine. 2007;39:130-7.

29. Lachgar S, Charveron M, Bouhaddioui N, Neveux Y, Gall Y, Bonafe JL. Inhibitory effects of bFGF, VEGF and minoxidil on collagen synthesis by cultured hair dermal papilla cells. Arch Dermatol Res. 1996;288:469-73.

30. Nataf $\mathrm{V}$, Tsagris L, Dumontier MF, Bonaventure J, Corvol M. Modulation of sulfated proteoglycan synthesis and collagen gene expression by chondrocytes grown in the presence of bFGF alone or combined with IGF1. Reprod Nutr Dev. 1990;30:331-42.

31. Camilleri S, McDonald F. Runx2 and dental development. Eur J Oral Sci. 2006;114:361-73.

32. Komori T. Signaling networks in RUNX2-dependent bone development. J Cell Biochem. 2011;112:750-5.

33. Lombardi G, Perego S, Luzi L, Banfi G. A four-season molecule: osteocalcin Updates in its physiological roles. Endocrine. 2015;48:394-404.

34. Karsenty G. Update on the biology of osteocalcin. Endocr Pract. 2017;23:1270-4.

35. Wu J, Huang GT, He W, Wang P, Tong Z, Jia Q, et al. Basic fibroblast growth factor enhances stemness of human stem cells from the apical papilla. J Endod. 2012;38:614-22.

36. An S, Huang X, Gao Y, Ling J, Huang Y, Xiao Y. FGF-2 induces the proliferation of human periodontal ligament cells and modulates their osteoblastic phenotype by affecting Runx2 expression in the presence and absence of osteogenic inducers. Int J Mol Med. 2015;36:705-11.

37. Teplyuk NM, Haupt LM, Ling L, Dombrowski C, Mun FK, Nathan SS, et al. The osteogenic transcription factor Runx2 regulates components of the fibroblast growth factor/proteoglycan signaling axis in osteoblasts. J Cell Biochem. 2009:107:144-54.

38. Zweifler LE, Patel MK, Nociti FH Jr, Wimer HF, Millan JL, Somerman MJ, et al. Counter-regulatory phosphatases TNAP and NPP1 temporally regulate tooth root cementogenesis. Int J Oral Sci. 2015;7:27-41.

39. Kyono A, Avishai N, Ouyang Z, Landreth GE, Murakami S. FGF and ERK signaling coordinately regulate mineralization-related genes and play essential roles in osteocyte differentiation. J Bone Miner Metab. 2012;30:19-30.

40. Foster BL, Nagatomo KJ, Tso HW, Tran AB, Nociti FH Jr, Narisawa S, et al. Tooth root dentin mineralization defects in a mouse model of hypophosphatasia. J Bone Miner Res. 2013;28:271-82.

41. Beck GR, Jr. Inorganic phosphate as a signaling molecule in osteoblast differentiation. J Cell Biochem 2003;90:234-243.

42. Conrads KA, Yu LR, Lucas DA, Zhou M, Chan KC, Simpson KA, et al. Quantitative proteomic analysis of inorganic phosphate-induced murine MC3T3-E1 osteoblast cells. Electrophoresis. 2004;25:1342-52.

43. Conrads KA, Yi M, Simpson KA, Lucas DA, Camalier CE, Yu LR, et al. A combined proteome and microarray investigation of inorganic phosphateinduced pre-osteoblast cells. Mol Cell Proteomics. 2005:4:1284-96.

44. Fatherazi S, Matsa-Dunn D, Foster BL, Rutherford RB, Somerman MJ, Presland RB. Phosphate regulates osteopontin gene transcription. J Dent Res. 2009;88:39-44.

45. Sodek J, Ganss B, McKee MD. Osteopontin. Crit Rev Oral Biol Med. 2000;11: 279-303.

46. McKee MD, Hoac B, Addison WN, Barros NM, Millan JL, Chaussain C. Extracellular matrix mineralization in periodontal tissues: noncollagenous matrix proteins, enzymes, and relationship to hypophosphatasia and Xlinked hypophosphatemia. Periodontol 2000. 2013;63:102-22.

47. Salmon B, Bardet C, Coyac BR, Baroukh B, Naji J, Rowe PS, et al. Abnormal osteopontin and matrix extracellular phosphoglycoprotein localization, and odontoblast differentiation, in X-linked hypophosphatemic teeth. Connect Tissue Res. 2014;55(Suppl 1):79-82.

48. Foster BL, Ao M, Salmon CR, Chavez MB, Kolli TN, Tran AB, et al. Osteopontin regulates dentin and alveolar bone development and mineralization. Bone. 2018;107:196-207.

49. Boskey AL, Spevak L, Paschalis E, Doty SB, McKee MD. Osteopontin deficiency increases mineral content and mineral crystallinity in mouse bone. Calcif Tissue Int. 2002;71:145-54.

50. Yadav MC, Huesa C, Narisawa S, Hoylaerts MF, Moreau A, Farquharson C, et al. Ablation of osteopontin improves the skeletal phenotype of phospho1(-/-) mice. J Bone Miner Res. 2014;29:2369-81.
51. Saito K, Nakatomi M, Ida-Yonemochi H, Ohshima H. Osteopontin is essential for type I collagen secretion in reparative dentin. J Dent Res. 2016;95:1034-41.

52. Berendsen AD, Smit TH, Schoenmaker T, Walboomers XF, Harris SE, Everts V, et al. Inorganic phosphate stimulates DMP1 expression in human periodontal ligament fibroblasts embedded in three-dimensional collagen gels. Cells Tissues Organs. 2010;192:116-24.

53. Ye L, MacDougall M, Zhang S, Xie Y, Zhang J, Li Z, et al. Deletion of dentin matrix protein-1 leads to a partial failure of maturation of predentin into dentin, hypomineralization, and expanded cavities of pulp and root canal during postnatal tooth development. J Biol Chem. 2004;279:19141-8.

54. Feng JQ, Ward LM, Liu S, Lu Y, Xie Y, Yuan B, et al. Loss of DMP1 causes rickets and osteomalacia and identifies a role for osteocytes in mineral metabolism. Nat Genet. 2006;38:1310-5.

55. Sinha KM, Zhou X. Genetic and molecular control of osterix in skeletal formation. J Cell Biochem. 2013:114:975-84.

56. Kim TH, Bae CH, Lee JC, Kim JE, Yang X, de Crombrugghe B, et al. Osterix regulates tooth root formation in a site-specific manner. J Dent Res. 2015; 94:430-8.

57. Chen Z, Chen D, McCarthy TL, Centrella M, Zhang Y, Moeckel GW. Inorganic phosphate stimulates fibronectin expression in renal fibroblasts. Cell Physiol Biochem. 2012;30:151-9.

58. Mathew S, Tustison KS, Sugatani T, Chaudhary LR, Rifas L, Hruska KA. The mechanism of phosphorus as a cardiovascular risk factor in CKD. J Am Soc Nephrol. 2008;19:1092-105.

59. Gurley KA, Chen H, Guenther C, Nguyen ET, Rountree RB, Schoor M, et al. Mineral formation in joints caused by complete or joint-specific loss of ANK function. J Bone Miner Res. 2006;21:1238-47.

60. Beertsen W, VandenBos T, Everts V. Root development in mice lacking functional tissue non-specific alkaline phosphatase gene: inhibition of acellular cementum formation. J Dent Res. 1999;78:1221-9.

61. Nociti FH Jr, Berry JE, Foster BL, Gurley KA, Kingsley DM, Takata T, et al. Cementum: a phosphate-sensitive tissue. J Dent Res. 2002;81:817-21.

62. Osathanon T, Giachelli CM, Somerman MJ. Immobilization of alkaline phosphatase on microporous nanofibrous fibrin scaffolds for bone tissue engineering. Biomaterials. 2009;30:4513-21.

63. Hacchou Y, Uematsu T, Ueda O, Usui Y, Uematsu S, Takahashi M, et al. Inorganic polyphosphate: a possible stimulant of bone formation. J Dent Res. 2007;86:893-7.

64. Rodriques TL, Nagatomo KJ, Foster BL, Nociti FH, Somerman MJ. Modulation of phosphate/pyrophosphate metabolism to regenerate the periodontium: a novel in vivo approach. J Periodontol. 2011;82:1757-66.

65. Lee TH, Kim WT, Ryu CJ, Jang YJ. Optimization of treatment with recombinant FGF-2 for proliferation and differentiation of human dental stem cells, mesenchymal stem cells, and osteoblasts. Biochem Cell Biol. 2015;93:298-305.

66. Fakhry A, Ratisoontorn C, Vedhachalam C, Salhab I, Koyama E, Leboy P, et al. Effects of FGF-2/-9 in calvarial bone cell cultures: differentiation stagedependent mitogenic effect, inverse regulation of BMP-2 and noggin, and enhancement of osteogenic potential. Bone. 2005:36:254-66.

67. Kartal Y, Ucok C, Ozgul O, Doruk Kocyigit I, Tolga Suer B. Effect of locally applied bFGF on implant stability: biomechanical evaluation of 2 different implant surfaces in rabbits. Implant Dent. 2014;23:463-70.

68. Zou GK, Song YL, Zhou W, Yu M, Liang LH, Sun DC, et al. Effects of local delivery of bFGF from PLGA microspheres on osseointegration around implants in diabetic rats. Oral Surg Oral Med Oral Pathol Oral Radiol. 2012;114:284-9.

69. Li F, Yu F, Xu X, Li C, Huang D, Zhou X, et al. Evaluation of recombinant human FGF-2 and PDGF-BB in periodontal regeneration: a systematic review and meta-analysis. Sci Rep. 2017;7:65.

70. Hoshi S, Akizuki T, Matsuura T, Ikawa T, Kinoshita A, Oda S, et al. Ridge augmentation using recombinant human fibroblast growth factor-2 with biodegradable gelatin sponges incorporating beta-tricalcium phosphate: a preclinical study in dogs. J Periodontal Res. 2016;51:77-85.

71. Chen M, Song K, Rao N, Huang M, Huang Z, Cao Y. Roles of exogenously regulated bFGF expression in angiogenesis and bone regeneration in rat calvarial defects. Int J Mol Med. 2011;27:545-53.

72. Du M, Zhu T, Duan X, Ge S, Li N, Sun Q, et al. Acellular dermal matrix loading with bFGF achieves similar acceleration of bone regeneration to BMP-2 via differential effects on recruitment, proliferation and sustained osteodifferentiation of mesenchymal stem cells. Mater Sci Eng C Mater Biol Appl. 2017;70:62-70 